\title{
Councils of the Judiciary and Judges' Perceptions of Respect to Their Independence in Europe
}

\author{
Pablo José Castillo Ortiz ${ }^{1,2}$
}

(C) The Author(s) 2017. This article is an open access publication

\begin{abstract}
Councils of the Judiciary have spread in Europe under the assumption that they contribute to a central aspect of the Rule of Law: the independence of courts and judges under their authority. However, a recent survey of the European Network of Councils of the Judiciary showed that, in some countries, there are significant groups of judges that perceive their Judicial Council as disrespectful of their autonomy. While in countries such as Denmark or Belgium judicial distrust of the Council seems to be anecdotal, in other countries such as Spain a striking 36 per cent of respondent judges had such negative views of the institution. With the aid of multi-value Qualitative Comparative Analysis, this paper explains the causes of this paradoxical phenomenon. It is argued that judges hold such negative opinions of Councils of the Judiciary as the result of the interaction between institutional, political and socio-legal conditions: the range of powers of the Councils, their control by political elites and interest groups, and the degree of judicial corruption.
\end{abstract}

Keywords Councils of the Judiciary $\cdot$ Judicial independence $\cdot$ Judicial associations · Judicial Politics · Qualitative Comparative Analysis

(QCA)

Pablo José Castillo Ortiz

p.castillo-ortiz@sheffield.ac.uk

1 Lecturer in Law, University of Sheffield, Winter Street, Sheffield S37ND, UK

2 Former Visiting Fellow, Institute of Advanced Legal Studies, University of London, London, UK 


\section{Introduction: The Paradoxical Relation Between Councils of the Judiciary and Judicial Independence}

In recent decades, Councils of the Judiciary have consolidated in Europe as one of the most wide-spread mechanisms for the governance of the judicial branch. In the words of Beers (2012: 51) these institutions can be defined as 'constitutionally mandated bodies endowed with the legal authority to manage the careers of judges, independent of government influence and oversight'. According to Bell (2006: 27) the concept of Judicial Council was invented in France in the late 19th Century, linked to the idea of an institution designed to protect the independence of the judiciary. With this background, the first modern Judicial Council was the French Conseil Supérieur de la Magistrature of 1946, followed by the Italian Consiglio Superiuore della Magistratura, authorised in 1948, but implemented in 1958 (Haley 2006: 86). In the current European context, the importance of these institutions is reflected in the existence of a European Network of Councils of the Judiciary, formed by 22 members.

Councils of the Judiciary from different countries have in common the function of management of certain aspects of the judicial branch. Yet beyond this common feature, the fact is that they display a wide variation, both with regards to their institutional design and their powers. While some of them have competences in vital aspects of the judiciary - such the management of the careers of judges - others have essentially advisory functions. While in some countries career judges determine the board of the councils, in other countries politicians remain in control of the appointments. Indeed, Bobek and Kosar (2013) differentiate at least three types of judicial councils in Europe, including 'the judicial council model' of strong institutions with a variety of competences, the 'courts service model' in which the councils have notably fewer powers, and 'hybrid' models which combine features of the two other types.

In general, one of the foundational goals of the Judicial Councils is the maximisation of judicial independence, which is central to the idea of Rule of Law. However, the extent to which these institutions have managed to achieve this objective remains in fact a contested issue. General definitions of Councils of the Judiciary insist in their a priori function of safeguarding the judiciary from political influences. Garoupa and Ginsburg (2009a: 106) state that Councils of the Judiciary are 'designed to insulate the functions of appointment, promotion and discipline of judges from the partisan politics process while ensuring some level of accountability'. In the same vein, Beers (2012: 51) considers that these institutions are 'designed to insulate the judiciary from overt political influence while placing the responsibility of governing and monitoring judicial behavior in the hands of independent judicial authorities'. From this perspective, judges should generally perceive Councils of the Judiciary as a guarantee for the protection of their autonomy. However, at the same time, a strand of literature has argued that, far from improving judicial independence, Councils of the Judiciary have often failed in achieving such a goal (Haley 2006, p. 87; Bobek and Kosar 2013, p. 4) or even have sometimes contributed to continuing political control over the judiciary (Beers 2012, p. 54). 
A recent survey of the European Network of Councils of the Judiciary (2014-2015) added further mystery to this academic controversy, illustrating that judges in different countries have largely divergent views of their councils. When asked whether they perceived that their Council of the Judiciary had respected their independence in the last years, the share of negative responses was extremely low just 3 per cent - for councils such as the Belgian, Polish or Danish ones. However, that share was much higher for some countries: it was of 10 per cent in Italy, 15 per cent in Bulgaria, 21 per cent in Portugal, and a shocking 36 per cent for the case of Spain. What explains the paradoxical cases of significant shares of judges perceiving that an institution designed to protect their independence is disrespectful of their autonomy?

This paper attempts to provide a first response to this question. At the academic level, this research contributed to our knowledge of clearly under-studied judicial institutions such as Judicial Councils. Despite their central role in the judicial and political systems of many European countries, our knowledge of Councils of the Judiciary, especially at the empirical level, is extraordinarily limited (but see, inter alia, Garoupa and Ginsburg 2009a, b; Popova 2012; Beers 2012). At the practical level, solving the research puzzle has the potential to contribute to evidence-based inputs to the debate about the improvement of our judicial systems. In particular, it helped us understand which features of the Councils facilitate a smooth relationship with judges, and which concrete aspects of those institutions have a negative effect on the judicial perception of respect to their independence. To do so, this article performed a multi-value Qualitative Comparative Analysis (mvQCA) using the QCA-GUI pack for R (Dusa 2007; see methodological section below). The evidence found suggested that the solution to the research puzzle lies in the interaction of different aspects of the Councils. On the one hand, in certain key elements of the design of these institutions, which structure their relations with both political actors and with the judiciary, such as the range of powers of the Council and the mechanism for appointment of members. On the other hand, socio-political and socio-legal aspects, such as the role played by interest groups operating within the judiciary and practices of judicial corruption, also seemed to play an important role.

The remainder of this article is structured as follows. After this introduction, the theory and configurational hypotheses of the research will be outlined. Subsequently, the main methodology of the article (mvQCA) will be explained, and the sources and operationalisation of the phenomena will be described and justified. Thereafter, the empirical section of the article presents the analyses of sufficient conditions for the multi-value outcome, namely country-level judicial assessments of respect of Councils of the Judiciary for judicial independence. The last section contains the concluding remarks to the article.

\section{Theory and Configurational Hypotheses}

Judicial independence is a central aspect of the Rule of Law, because in its absence the enforcement of law by courts can suffer from systematic bias and lack of impartiality. The idea of judicial independence has been the object of countless 
definitions in literature in political science and empirical legal studies, but the common focus of many authors is the idea of judicial capacity to make decisions unconstrained from political interference. Rosemberg (1992: 369) defined judicial independence as 'the ability of courts to make decisions in the short term without regard for preferences of officeholders'. For Ferejohn (1998-1999: 335) one of the dimensions of judicial independence refers to 'the idea that a judge ought to be free to decide the case before him or her without fear or anticipation of (illegitimate) punishment or rewards'. Given the central role of independence and neutrality in the legitimising narrative of judicial-type institutions, it is not surprising that modern democratic systems have created different arrangements to protect it.

Councils of the Judiciary are one of those arrangements. However, in practice, we know that judges not always consider their Councils of the Judiciary simply as a protection of their independence, but sometimes also as a threat to it. Drawing on existing literature in the field, this section puts forward four potential explanations for this paradoxical phenomenon. While some of these explanations suggest that a modicum of constraint on judges is a natural consequence of the very existence of Councils of the Judiciary centralising powers to manage the court system, other possible explanations suggest that perception of judges of disrespect for their independence is the direct result of flawed institutional designs of the Councils. Furthermore, far from being competing and mutually exclusive, it is argued that all these explanations combine to produce different results in each case.

- Appointment. In their publications about Councils of the Judiciary, Garoupa and Ginsburg (2009a: 131) argued that both independence and political accountability were desirable goals when designing these institutions. However, they also suggested that in pursuing accountability Councils may end up suffering an excess of political control (Garoupa and Ginsburg 2009b, p. 77). The forms of appointment of the members of the Councils of the Judiciary are central to this idea. These forms of appointment display a great degree of variation across countries, ranging from parliamentary appointments to different forms of election by the members of the Judicial Branch. In general, control of appointment by the judiciary has emerged as a good practice in the European context. The European Network of Councils of the Judiciary stated in a recent report that 'the mechanism for appointing judicial members to a Council must be a system which excludes any executive or legislative interference and the election of judges should be solely by their peers' (ENCJ 2010-2011: 5). The importance of the mechanism of appointment is also acknowledged in academic literature. According to Guarneri (2013: 350) 'at least in principle, judicial independence will be stronger with a higher ratio of members chose directly by and from the judiciary'. Thus, it can be expected that political control over the appointment of members of the Council will contribute to a better perception of the institution as disrespectful of judicial independence.

- Range of powers. According to Hall and Taylor (1996: 939), one of the core features of neo-institutionalist theories is that they seek 'to elucidate the role that institutions play in the determination of social and political outcomes'. Together with the procedure of appointment of members, one of the core aspects of the 
institutional design of Councils of the Judiciary is their range of powers. Indeed, this aspect is essential to understand judges' perception of respect to their independence. As suggested by Guarneri (2013: 350), it can be expected that the more extensive their functions, the stronger the role of the Councils. However, powerful Councils are Janus-faced. On the one hand, when a Council of the Judiciary accumulates power over judges it might be taking that power away from political actors. On the other hand, however, the same powers that should allow Councils to protect judicial independence might be potentially used to curtail it. For instance, Garoupa and Ginsburg (2009a: 120) argued that competences such as those related to the organisation and running of the judiciary, appointment or performance evaluation provide material incentives that can be used to reward certain sorts of judges. Bobek and Kosar (2013: 14) went even further; for the authors, the powers of the institution can be easily misused: 'The Euro-model shields the judiciary from external influence, but it pays little attention to improper pressure on individual judges (...) [It] empowers only a narrow group of judges who in turn may favour their allies and shape the judiciary according to their views'. Therefore, a wider range of powers of the Councils should contribute to a reduction in the perception of the institutions as detrimental of judicial independence.

- Associations of judges. The associations of judges are another phenomena largely underexplored in international research, which this article covers. In the words of Beers (2012: 51), they can be defined 'voluntary organizations designed to serve the professional interests of judges'. The nature and types of associations are not, however, homogeneous across Europe. Bell (2006: 371) distinguishes two different models of judicial associations, one in which these represent the different political views of judges and another in which they behave like professional associations with the aim to bringing together all members of the judiciary. Beers (2012: 51) has considered associations as institutions of judicial self-government, but has also acknowledged the 'potentially harmful impact' of poorly functioning ones. This is important to the explanation of Councils of the Judiciary, because judicial associations often play a role in the life of these institutions. Indeed, as put by Guarneri (2013: 350), certain Councils have strengthened the role of associations, so that they 'organise the participation of judges in elections to the council'. Thus, it can be considered that judicial associations that are perceived as detrimental to judicial independence will contribute to the perception of Councils of the Judiciary as being disrespectful of such independence.

- Judicial corruption. A final explanatory argument deals with judicial corruption, which has recently emerged as one of the newest concerns of literature in the field (see inter alia Guarneri 2007: 209; Beers 2012; Popova 2012). Case-based literature has suggested that the extensive powers of a Council and its insulation from any form of accountability is causally linked to judicial corruption (Popova 2012). In a similar vein, the introduction of a Council of the Judiciary has been blamed as responsible for increasing judicial nepotism (Bobek and Kosar 2013, p. 25). From a theoretical viewpoint, if a Council is corrupt, judges will perceive it as a threat to their independence. Councils will also be perceived as 
detrimental to judicial independence if they are unable to protect the judiciary from external sources of corruption. In the latter case, they will be deemed as unable to fulfill their basic function of protecting the integrity and reputation of the judiciary, and blamed for the deterioration of the Judicial Branch. Thus, the element of corruption could contribute to a greater perception of the Councils as being detrimental to judicial independence.

As said above, rather than having individual impact on the outcome of the research, these four conditions are expected to combine in different forms in each case. For that reason, and following the common practice in QCA, hypotheses will be formulated in a configurational way in this article. Configurational hypotheses do not hypothesise about all potential configurations of conditions, but rather about some of them that are particularly plausible.

Take for instance the relationship between the powers of the Council and the mechanism of appointment of its members. In line with rational choice institutionalism, politicians might be assumed to be rational actors seeking to maximise their power under institutional constraints (inter alia Kato 1996, p. 568; Shepsle 2006, p. 28). In the instance explored by this article, the control of the Council provides politicians power over the judiciary as a whole: powerful councils appointed by politicians enhance rather than limit political control over judges. As Magalhaes (1999: 44) suggested, institutional designs influence the extent to which political majorities can affect the composition of courts 'by allowing or preventing the appointment of judges whose preferences are known to be close to the majorities' and therefore by increasing or decreasing the likelihood of judicial decisions that favor their interests'. In this regard, the range of powers of the Council might become a tool for political subjugation: 'The rules regarding the management of judicial careers influence the responsiveness of judiciaries to dominant political actors' (Magalhaes 1999, p. 44). For that reason, the first configurational hypothesis would pose that:

$\mathrm{H}_{1}$. Councils with a wide range of powers and whose members are appointed by political actors will be perceived by judges as disrespectful of their independence

The second hypothesis links the range of powers of the Council with the general perception of corruption in the judiciary. When a Council has a wide range of powers, it is its responsibility to hold judges accountable for their actions. In these cases, it is the task of the Councils to keep the judiciary free from unethical practices, and therefore cases of corruption can be deemed to be the result of the Councils ineptitude, inaction or even acquiescence. Furthermore, when the Council has a wide range of powers and it is not subject to political control, it might be the very Council that engages in practices of corruption. In all these cases, the loss of independence that judges experience as a result of the constraints imposed by corruption upon the judiciary will be blamed on the Council, which might be seen as a direct or indirect threat to such independence. For that reason the second configurational hypothesis would suggest that: 
$\mathrm{H}_{2}$. Councils with a wide range of powers in countries where judicial corruption is perceived as widespread will be deemed by judges as disrespectful of their independence.

\section{Data and Methods}

To account for judges' assessments of their Council of the Judiciary this article used the survey recently carried out by the European Network of Councils of the Judiciary (ENCJ). The ENCJ sent a questionnaire to a number of national Councils of the Judiciary, which these distributed among their national judges. According to the ENCJ, the reason was the acknowledgement that 'judges had never been systematically asked about subjective independence', so a survey was conducted in which 22 judicial organisations and 5,878 judges participated (ENCJ 2014-15, p. 6). However, it must be noted that some European countries with a Council of the Judiciary did not participate of the survey. The survey asked about a variety of topics, including perceived individual independence of the judge, perceived independence of the judiciary as a whole, and perception of respect to judicial independence by different organisations. The response rates ranged from 3 per cent (Portugal) to more than 40 per cent (Scotland), so the sample sizes are proportionally much larger than those of most surveys in neighboring disciplines, such as electoral behavior. This data was extremely valuable given that it is the only available source of information on this topic so far. However, it has two important caveats.

First, given that national judges were free to respond to the survey, the possibility of a self-selection bias cannot be ruled out. For that reason, and although a recent empirical study of the Dutch Council of the Judiciary has also made use of this database (Van Dijk et al. 2016), the results of this article must be read with caution. Second, the responses of the individual judges to the survey were not made publicly available. While the ENCJ was willing to grant this data to individual researchers, the general public distribution of the data was not allowed, and this impeded replicability of any individual-level analysis. For this reason, this research only uses the publicly available aggregated data of the survey, together with other aggregated and country-level explanatory conditions, to carry out the analysis. Given these two methodological limitations, the analyses of this article should be interpreted with caution and only as an exploratory first step in responding to this important research question.

To test the research hypotheses, this article uses Qualitative Comparative Analysis (QCA), as this methodology is particularly powerful in examining causal relations for small and moderate $\mathrm{N}$ datasets, and more efficient than stochastic techniques in samples of such size. Additionally, the epistemological assumptions of QCA are especially apt to understand complex causation and the interaction between explanatory conditions, and turned out to be very useful in analyzing a meso level object of study such as the Councils of the Judiciary scrutinised by this article. While the usual space constraints prevent this section from explaining in detail the functioning of QCA, it will provide for clarification of key concepts and 
justification of the modalities of analysis and operationalisation of the conditions used, in line with the best practices in the use of the methodology (Schneider and Wagemann 2010). Readers wishing to learn more about QCA will find many handbooks and user guides about this set of techniques especially useful (inter alia, Rihoux and Ragin 2009a; Schneider and Wagemann 2012).

QCA takes a configurational approach to causation, in which it is the interaction between explanatory conditions - rather than their autonomous impact - which drives outcomes (Rihoux and Ragin 2009b: xix). As put by Berg-Schlosser et al. (2009: 6) in QCA 'each individual case is considered as a complex combination of properties, a specific "whole" that should not be obscured in the course of the analysis'. Given the nature of the object of study of the research, this article uses the 'multi-value' variant of QCA. The reason is that this allows to better capture of the subtleties of some of the conditions and the outcome. For instance, the condition 'appointment of members' admitted three qualitatively different forms of appointment (judicial, political and hybrid). Likewise, the option for a multi-value outcome allowed a more fine-tuned understanding of the phenomena explored, distinguishing cases of low, moderate, and high perception of disrespect for judicial independence. To perform the analysis, the QCA-GUI pack (see Dusa 2007) for R was used. This software presents two important advantages when performing mvQCA analysis visà-vis other informatic programmes. First, it includes coverage and consistency indicators for the mvQCA solutions. Second, it allows the specification of directional expectations when working with logical reminders. To the best of this author's knowledge, this is the first multi-value analysis applying this software to the analysis of legal institutions.

Table 1 reports all the conditions used in this research, the sources of information and the operationalisation of the conditions. Since missing values are generally problematic in configurational analysis, the research is circumscribed to the Councils of the Judiciary covered by all the sources of information. When more than one council existed for a judiciary, the more general one was used. For instance, in Italy the Consiglio Superiore della Magistratura was taken as a reference, leaving aside the more specialised Consiglio di Presidenza della giustizia amministrativa. The size of the resulting sample was of 17 institutions. These included institutions in countries with a variety of legal, social and historical contexts, including countries from different European sub-regions, countries that ascribe to different legal traditions and countries whose democracies exhibit different degrees of consolidation. This diversity of background conditions was considered a strength of the research. However, out of these 17 cases three of them showed a logical contradiction: the councils of Scotland, Northern Ireland and Latvia, which had the same value in all conditions, but had different outcomes. This research opted for a conservative approach and did not include contradictory configurations in the minimisation. The potential reasons for this contradiction are varied. Note that for the condition 'corruption' only values for the UK as a whole were available, so the three British councils had the same score. Given that England and Wales is the biggest jurisdiction, it is very likely that such values are more representative of this council than of those of Northern Ireland and Scotland. Also, some idiosyncratic factors mentioned by the literature for the case of Northern Ireland might have 
Table 1 Source and operationalisation of conditions

\begin{tabular}{|c|c|c|}
\hline Condition & Source & Operationalisation \\
\hline $\begin{array}{l}\text { Council disrespectful of } \\
\text { independence } \\
\text { [outcome] }\end{array}$ & $\begin{array}{l}\text { ENCJ } 2014-15 \text { Report, question } 8.4 \text { : } \\
\text { During the last two years I believe that my } \\
\text { independence as a judge has been respected by the } \\
\text { Council for the Judiciary (disagree/strongly } \\
\text { disagree). }\end{array}$ & $\begin{array}{l}\{0\}=x<4.5 \\
\{1\}=4.5>x<9.5 \\
\{2\}=x>9.5\end{array}$ \\
\hline $\begin{array}{l}\text { Association disrespectful } \\
\text { of independence }\end{array}$ & $\begin{array}{l}\text { ENCJ 2014-15 Report, question } 8.7 \text { : } \\
\text { During the last two years I believe that my } \\
\text { independence as a judge has been respected by the } \\
\text { Association of Judges (disagree/strongly disagree). }\end{array}$ & $\begin{array}{l}\{0\}=x<6.5 \\
\{1\}=x>6.5\end{array}$ \\
\hline Powers of the Council & $\begin{array}{l}\text { EU Justice Scoreboard 2016, Figure 50: Powers of the } \\
\text { Councils for the Judiciary. }\end{array}$ & $\begin{array}{l}\{0\}=x<6 \\
\{1\}=x>6\end{array}$ \\
\hline Corruption & $\begin{array}{l}\text { Global Corruption Barometer } 2013 \text { and 2010-11: } \\
\text { To what extent do you perceive the following } \\
\text { institutions in this country [judiciary] to be affected } \\
\text { by corruption? (1-not corrupt at all, 5-extremely } \\
\text { corrupt). }\end{array}$ & $\begin{array}{l}\{0\}=x<3.8 \\
\{1\}=x>3.8\end{array}$ \\
\hline Appointment & $\begin{array}{l}\text { EU Justice Scoreboard 2016. Figure } 49 \\
\text { ENCJ website (Member factsheets). } \\
\text { Secondary literature. }\end{array}$ & $\begin{array}{c}\{0\}=\text { Mainly } \\
\text { judicial or } \\
\text { apolitical } \\
\{1\}=\text { Hybrid } \\
\{2\}=\text { Mainly } \\
\text { political }\end{array}$ \\
\hline
\end{tabular}

played a role, inter alia the very small size of its judiciary, the importance of interpersonal relations in this context, or the 'long period of political conflict and violence' which 'has inevitably been a defining feature of the institutional and cultural shape of the judiciary' (Gee et al. 2015, p. 226). The exclusion of contradictory configurations from minimisation is not hidden in the results. On the contrary, is transparently showed in the solution models, and in particular reflected in the consistency scores. The exclusion of contradictory configurations means that solution consistency scores will not be perfect, although as showed in the empirical section this indicator is still satisfactorily high for all models.

As mentioned earlier, for the outcome the source of data was the recent 2014-15 report of the European Network of Councils of the Judiciary on 'Accountability of the Judiciary and of the Prosecution'. The question to judges whether they felt that their Council of the Judiciary had respected their independence was used. In particular, the outcome was constructed taking into account the share of negative responses to that question, excluding from the operationalisation positive responses or NS/NA responses. This means the research explains the causes of the existence of large, medium or small groups of judges regarding their Council as disrespectful of independence, rather than the perceptions of national judiciaries as a whole. The first value of the outcome $(\{0\})$ included cases with less than 4.5 per cent of 
negative responses, the second value $(\{1\})$ included cases with shares ranging from 4.5 to 9.5 , and the third value $(\{2\})$ included cases with a share of negative responses higher than 9.5. The multi-value outcome allowed a more fine-tuned analysis. At the same time, the operationalisation allowed a balanced distribution of cases in each of the three values of the outcome. As QCA-GUI is prepared to work with multi-value conditions, but not with multi-value outcomes, three databases were created, using a crisp-set for each of the values of the outcome, the values of the rest of conditions remaining unaltered.

To account for the threat posed by judicial associations, the 2014-15 Report of the ENCJ was used again. In particular, the source of data was the question 8.7 that asked judges whether they perceived their judicial association had respected their independence. As with the outcome, the operationalisation of the condition took into account the share of negative responses. Such negative responses registered a significant cross-country variation, and ranged from 1 to 11 percent of surveyed judges. The dichotomisation point chosen was 6.5, an intermediate point in the distribution that marked the transition towards the existence of a significant minority perceiving associations as disrespectful of independence.

To assess the powers of the Councils, the index provided by the 2016 EU Justice Scoreboard of the European Commission was followed. This index aggregated eleven issues (including, inter alia, powers of appointment, promotion of judges, or budgetary powers), giving each of them a score of 1 point, so that the index could range from 0 to 11 . The dichotomisation point was 6 , the point in which the largest gap in the data was observed, and which again allowed a balanced distribution of cases in the presence and absence of the condition.

For corruption, the question about judicial corruption of the Global Corruption Barometer was followed. In general, the most recent edition (2013) was used, except for those cases not included on it, for which the previous edition (2010-11) was used. The possible responses ranged between 1 and 5, although actual national averages usually did not take extreme values and most cases had high values of 3 or more. The dichotomisation point was set at 3.8, with the aim of differentiating cases with a very high perception of corruption from the rest.

For appointment, a multi-value set with three categories was created. One category $(\{0\})$ included cases in which the appointment of members of the Judicial Council was essentially controlled by the judiciary or at least there was no political control over appointments (Ireland, Italy, Latvia, Lithuania, Poland, England and Wales, Scotland, Northern Ireland). Another category ( $\{2\})$ included cases in which political actors had the last word for the appointment of the majority of members (Spain, Portugal and the Netherlands). Finally, another category $(\{1\})$ was created for hybrid or mixed procedures of appointment (Belgium, Bulgaria, Denmark, Romania, Slovakia, Slovenia). To assign the scores, the main sources of information were the member factsheets of the official ECNJ website, complemented with literature on the cases.

Table 2 below summarises all information for all conditions and for the construction of the data matrix. 


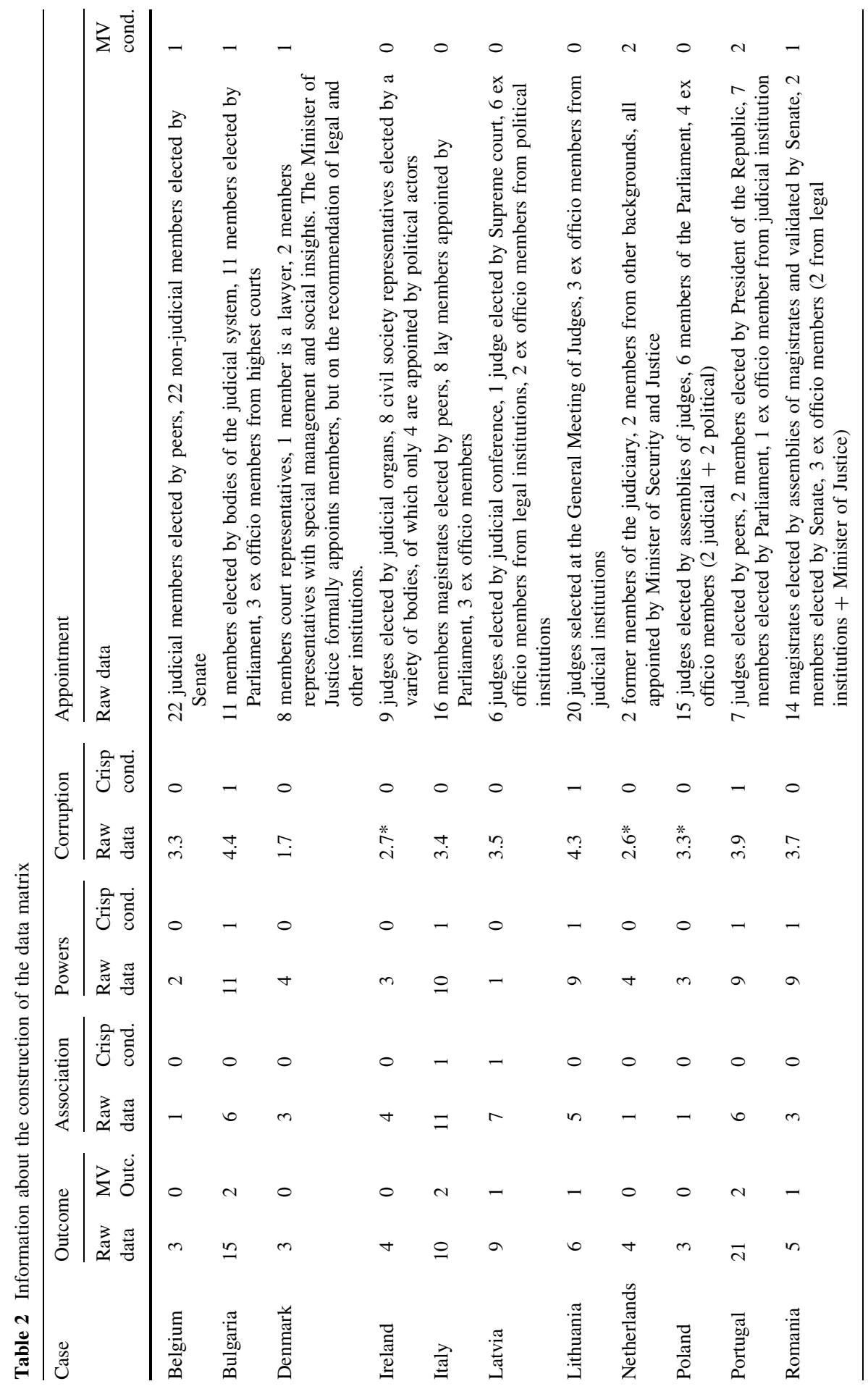




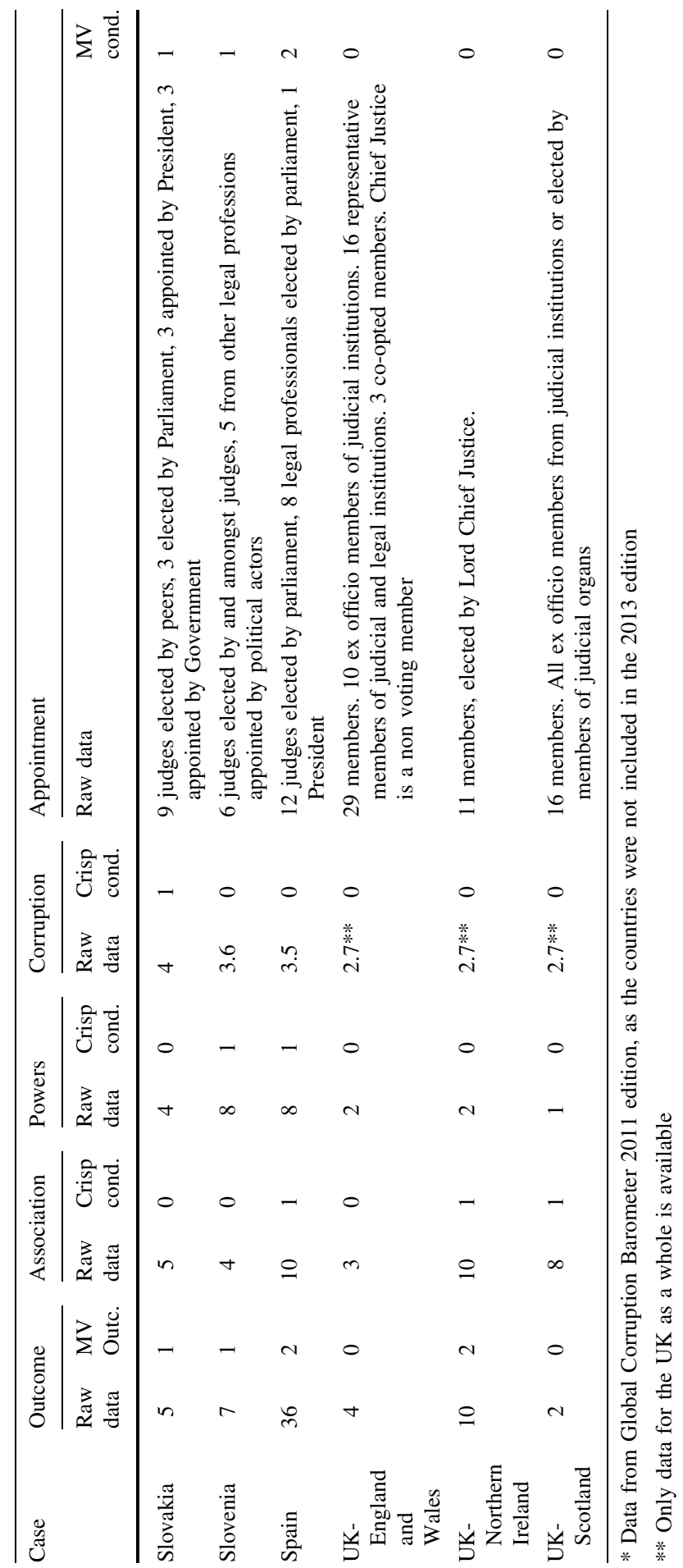




\section{Analysis}

\subsection{Cases of High Perception of Disrespect for Judicial Independence}

For cases such as Spain, Italy, Portugal, and Bulgaria, the share of judges reporting that they felt that their Council of the Judiciary was disrespectful of their independence was notably higher than for the rest of cases. To different extents, these four countries show the existence of a paradox that questions the performance of Judicial Councils: institutions created to protect the autonomy of judges were perceived by many of these as disrespectful of their independence. This subsection aims at discovering the causes of this striking phenomenon. To produce a QCA model capable of explaining such causes, four conditions were introduced in the analysis of sufficient conditions: the powers of the Council, appointment, corruption and associations. When introducing directional expectations, following the theoretical framework set out above, all the dichotomous conditions were expected to contribute to the outcome when present $(\{1\})$ and, in the case of the procedure of appointment, when controlled by political actors $(\{2\})$.

As showed by Table 3, the resulting model provided for four different paths, covering each of them a different case. Overall, the model had a perfect inclusion (1.000) and a very high coverage $(0.8000$, given that the exclusion of the contradictory case of Northern Ireland).

With 36 per cent of judges indicating disrespect to their independence, the Spanish Consejo General del Poder Judicial is by far the council obtaining the worse assessment in the survey. The first path explains the factors behind these clearly suboptimal results. It combines a wide range of powers together with a political procedure of appointment of members of the council coupled with highly

Table 3 Analysis of sufficient conditions for high perception of disrespect to independence

\begin{tabular}{lccccc}
\hline & Incl & PRI & cov.r & cov.u & Cases \\
\hline $\begin{array}{l}\text { ASSOCIA_THREAT }\{1\} \text { *POWERS }\{1\} \\
\text { *APPOINTMENT }\{2\}\end{array}$ & 1.000 & 1.000 & 0.200 & 0.200 & Spain \\
$\begin{array}{l}\text { ASSOCIA_THREAT }\{1\}{ }^{*} \text { POWERS }\{1\} \\
\text { *APPOINTMENT }\{0\}\end{array}$ & 1.000 & 1.000 & 0.200 & 0.200 & Italy $^{1}$ \\
$\begin{array}{l}\text { POWERS }\{1\} * \text { CORRUPT }\{1\} \\
\text { *APPOINTMENT }\{1\}\end{array}$ & 1.000 & 1.000 & 0.200 & 0.200 & Bulgaria \\
$\begin{array}{l}\text { POWERS }\{1\} * \text { CORRUPT }\{1\} \\
\text { *APPOINTMENT }\{2\}\end{array}$ & 1.000 & 1.000 & 0.200 & 0.200 & Portugal \\
Model & 1.000 & 1.000 & 0.800 & & \\
\hline
\end{tabular}

1 The software offered an alternative to this model, which was exactly the same in everything except for the path explaining Italy. Indeed, such alternative model gave almost the same explanation for the Italian case, only adding the absence of corruption to the path ('ASSOCIA_THREAT $\{1\} *$ POWERS $\{1\}\}^{*}$ CORRUPT $\{0\} *$ APPOINTMENT $\{0\}$ '). Given that this alternative solution was less parsimonious and less theoretically sound, it was discarded 
distrusted judicial associations. The path is in line with the first research hypothesis, although adding further complexity as it also includes the role of judicial interest groups. It is reminiscent of Guarneri's (2013: 347) depiction of some civil law countries in which 'The influence of the executive - and to some extent, also the legislature - on the judiciary has been exerted mainly thanks to senior judges in control of judicial promotions and owing their position to governmental influence', even if the Spanish council is not exclusively formed by senior members. In the Spanish case, both political actors and judicial associations had traditionally great control over the process of nomination and appointment of members of the Consejo General del Poder Judicial. From the 1980s onwards, both chambers of the Spanish parliament have had the final say in the appointment of members. According to Andrés Ibáñez (2003: 157), this allowed political parties to control the institution and, in the same vein, Nieto (2003: 388) denounced its politicisation. This political control is especially delicate as this Council is a powerful institution, with a very wide range of powers over essential aspects of the judiciary. The path also includes the perception of associations as disrespectful of independence. Associations, often linked ideologically to political parties (Nieto 2010, p. 26), had traditionally also had a leading role in the appointment of members of the council, as they controlled the nomination of candidates among which the parliament would make the appointment. A recent reform of the Spanish council, however, has relatively disempowered judicial associations, so it would be no surprise if future surveys to Spanish judges showed different perceptions of these actors. In general, the Spanish council is the best example of how a council can have a dysfunctional relationship with judges when it is bestowed with wide-ranging powers, which are however captured by political actors and/or interest groups.

The second path, covering the Italian Consiglio Superiore della Magistratura, shows almost the same combination of conditions as the path covering Spain, but now we observe a process of appointment of members of the council dominated by judges, rather than politicians. This difference might be important; the Italian council is still in the group of institutions most frequently perceived by judges as disrespectful of their independence, but the 10 per cent share of judges with this view in Italy is still far from the 36 per cent figure of Spain. Thus, while both models show weaknesses, the institutional establishment of the Spanish institution clearly drives to worsen the results compared to those of its Italian equivalent.

Despite being a model for many of its counterparts in Europe, the Italian Council has been criticised 'for corporativism, a lack of judicial accountability and suboptimal efficiency' (Bobek and Kosar 2013, p. 13). As indicated by the second path, the Italian Council is a powerful institution, and the literature suggests it 'controls virtually all aspects of judicial appointment and promotion for the ordinary judiciary', to the point that its composition 'was altered in 2002 to increase the influence of the Parliament' (Garoupa and Ginsburg 2009a, p. 108). The problem, however, seems to be related to the capacity of interest groups to capture the institution and control its power. As indicated by the path, precisely because the process of appointment of members was depoliticised and given to judicial associations, the latter have exercised an enormous control over the institution. The influence of the Italian judicial associations on the Council was recently 
acknowledged by noting that "no judicial member of the Higher Council of the Judiciary (Consiglio superior della magistratura) is likely to be elected without the backing of one of this groups' and since 'decision-making in the Higher Council is heavily dependent on alignments among them' (Guarneri 2007, p. 196; see also Garoupa and Ginsburg 2009b, p. 76). At the same time, far from purely apolitical, many associations in Italy have a clear ideological nature, as well as links with the political parties (Garuopa and Ginsburg 2009c, p. 466). They provide a clear instance of what Bell (2006: 371) calls the 'Latin model' of judicial associations in which these 'represent the divergent social and political outlooks among judges', and that could also be found in the Spanish case.

The third and fourth paths are relatively similar, and combine a powerful council, a high perception of judicial corruption, and hybrid (Bulgaria) or political (Portugal) procedures for the appointment of members of the institution. The paths, in fact, are in line with the second research hypothesis, although add further complexity when addressing the role appointment procedures. The Bulgarian case is particularly interesting, as it had the worse perception of corruption in the sample. Following the pressures of the EU, in 2003 and 2007 the Bulgarian Supreme Judicial Council was empowered with inspection and dismissal powers (Noutcheva and Bechev 2008, p. 133-135). According to Popova (2012: 38-39) the overall picture is one of a highly independent and powerful judiciary in Bulgaria. At the same time, however, the Global Corruption Barometer (2013) suggests that Bulgaria is remarkable for its level of judicial corruption. Popova (2012) links these two phenomena. For the author, the high judicial insulation of the judiciary of Bulgaria prevents the other branches of government or the public from punishing corrupt magistrates (Popova 2012, p. 43). This might explain the relevance of the 'hybrid' procedure of appointment, in which political elites have a certain role, but no total control over the institution. Thus, in the Bulgarian case, 'Judicial insulation seems to have removed the main incentive the judiciary has to undertake an anticorruption campaign' (Popova 2012, p. 46).

\subsection{Cases of Low Perception of Disrespect for Judicial Independence}

When analysing the responses to the question whether the Councils respected judicial independence, it was observed that for a number of cases the share of negative responses was in fact relatively low. All of them were Northern European countries, except for Poland. This subsection shows the combinations of conditions that drove to this more positive assessment of judicial councils by judges. In analysing this, the same four conditions as in the previous subsection were introduced in the model. Directional expectations were diametrically opposite to those for the presence of the outcome: all crisp conditions were expected to contribute to the absence of the outcome when absent $(\{0\})$. The multi-value 'appointment' condition was deemed to contribute to the outcome when controlled by the judiciary $(\{0\})$.

As displayed in Table 4, the model had a perfect inclusion (1.000) and a very high coverage ( 0.857 , given the exclusion of the contradictory case of Scotland). The path points at Councils of the Judiciary with limited powers, in which judicial associations are not perceived as a threat and with judiciaries perceived as scarcely 
Table 4 Analysis of sufficient conditions for low perception of disrespect to independence

\begin{tabular}{llllll}
\hline & Incl & PRI & cov.r & cov.u & Cases \\
\hline $\begin{array}{l}\text { ASSOCIA_THREAT }\{0\}\}^{*} \text { POWERS }\{0\} * \\
\text { CORRUPT }\{0\}\end{array}$ & 1.000 & 1.000 & 0.857 & - & $\begin{array}{c}\text { Denmark, Ireland, Poland, } \\
\text { Belgium, England and } \\
\text { Wales, Netherlands }\end{array}$ \\
Model & & & & & \\
\hline
\end{tabular}

corrupt. Given the limited scope of competences of these institutions, most of them are closer to what Bobek and Kosar (2013: 16) refer to as the 'court service model', in which the main functions of the councils refer to administration and management, or even 'hybrid models', than to the model of strong Judicial Councils. In some instances, in these countries the council delegate decision-making competences to professionals, which can be deemed as an interesting form of self-restraint. Additionally, and in contrast to countries such as Italy or Spain, some of these countries had associations of a more professional than ideological profile, in line with the characterisation provided by Bell (2006: 371).

The Dutch Raad voor de Rechtspraak is a very interesting example. Created in 2002 (Garoupa and Ginsburg 2009a, p. 111), its powers are essentially limited to adopting ethical standards, the promotion of judges, allocation of budget to courts and implementation of ICT in courts (European Commission 2016, p. 39). It lacks most of the rest of possible competences, including disciplinary decisions, appointment or dismissal of judges, etc. Equally interesting is the case of Poland, where according to Piana (2009) the council was born with limited powers, which were only moderately extended in the 2000s. At the moment, its competences are limited to adopt ethical standards, and to propose appointments and dismissal of first instance judges (European Commission 2016, p. 39). Additionally, the share of Polish judges considering their associations as not respecting their autonomy is insignificant (only 1 per cent). With this background, and in line with the theoretical expectations set above, the Polish council is among those receiving a better assessment by judges, with only 3 per cent considering it to be disrespectful of independence. However, the Polish judicial council illustrates very well the tradeoffs that these institutions face. The low distrust of Polish judges towards their judicial council, which is a priori a positive thing, is the result of an interaction of conditions in which the limited powers of such council play an important role. Yet, councils that lack significant competences are also less likely to have sufficient powers to protect judges from external pressures when these happen. In a moment in which the Polish Government is taking controversial action intended at weakening the Rule of Law mechanisms in this country, the existence of a weak Council of the Judiciary may be problematic. In this regard, it is telling that the Polish Government is planning reforms aimed at further disempowering the institution and further securing control over it. ${ }^{1}$

\footnotetext{
1 The Guardian, Polish judges urged to 'fight every inch' for their Independence, 26 February 2017, at https://www.theguardian.com/world/2017/feb/26/polish-judges-urged-fight-independence-supreme-court (26.04.2017).
} 
A third instance of this path is the Danish Domstolsstyrelsen. This council is very interesting as in some regards it represents better than any other institution the combination of conditions that compose the path, and in this regard it could be considered as paradigmatic. The Danish council had the lowest rate of perceived judicial corruption (an average of 1.7 in a 1 to 5 scale). It is also a relatively weak institution, with very limited powers (European Commission 2016, p. 39), which makes it an interesting instance of the 'court service model' (Bobek and Kosar 2013 , p. 16). And finally, in Denmark the perception of judicial associations as a threat to independence is notably low. The interaction among these conditions explains the high perception of the institution as respectful of judicial independence, fitting again the theoretical expectations of this article.

Finally, beyond the peculiarities of the cases, there are two aspects worth underlining in this model. Firstly, the irrelevance of the procedure of appointment, which disappeared after minimization. When all other conditions had the appropriate sign, judges did not perceive their councils as disrespectful of their independence regardless of the type of procedure of appointment and the actors involved in it. For instance, the Netherlands were included in this path, even if the Minister of Justice has the last word on appointments. It is worth noting that Garoupa and Ginsburg (2009b: 78) have stated that 'the Dutch case is a good example of a judicial system in which no serious concerns about excessive politicization have arisen'. A hypothesis to explain this is that when Councils are not powerful, the different actors -including politicians- have fewer incentives to play battles over their control. This hypothesis, however, might be questioned by the recent reforms proposed by the Polish government, described above. Secondly, it is interesting to note that institutional disempowerment is part of the configuration. This is important because, as suggested earlier, councils with limited competences have fewer tools to threat judicial independence, but this is at the risk of becoming weaker institutions. For instance, they might be potentially less able to protect judicial independence from other actors. This is not to say that in countries with disempowered councils judicial independence is always more likely to be undermined, as this may eventually be ensured through other institutional arrangements. However, it is also important to clarify that, in the absence of these other institutional arrangements, depriving councils of their powers in the hope that this will improve judicial assessments of the institution might be counterproductive.

\subsection{Cases of Moderate Perception of Disrespect for Judicial Independence}

A number of cases, all of them in post-communist countries, displayed moderate assessments of disrespect to judicial independence, ranging from 5 to 9 per cent of surveyed judges. All of these councils represented intermediate instances between the two sets of institutions analysed in the two previous subsections. To construct a model for these cases it was inappropriate to establish directional expectations, because what was likely to drive to moderate outcomes - as opposed to very high or very low - were actually different combinations of positive and negative conditions 
counter-balancing one another in different ways. For this reason, a conservative approach was taken and no remainders were included in the minimisation.

As indicated in Table 5, the model included three different paths, which together had a perfect inclusion (1.000) and a high coverage $(0.800$, given the contradictory case of Latvia). The first path, covering Slovakia, included a disempowered Council and low perception of disrespect to independence by associations, but a high perception of corruption and a hybrid model of appointment. The second path, covering Romania and Slovenia, had low perceptions of corruption and of disrespect to independence by associations, but powerful councils and hybrid models of appointment. And the third path, covering Lithuania, had good assessments of judicial associations and a procedure of appointment controlled by the judiciary, but a powerful council and a high perception of corruption. As advanced above, different combinations of conditions pointing in opposite directions provoked intermediate results.

Individual examples can illustrate the internal dynamics of some of the cases covered by the model. The first path can best be explained referring to the Slovak Súdna rada Slovenskej republiky. Its relative disempowerment should have a priori driven to a low perception of disrespect to independence. However, this combined with a hybrid procedure of appointment, a high perception of corruption, as well as a significant share of judges perceiving associations as disrespectful of their independence. Bobek and Kosar (2013: 24 et seq.) provide qualitative information about this case. While their depiction of this council as a powerful one does not exactly fit the information provided by the European Commission report (2016: 39), their assessment of this institution is generally coherent with the path. In line with the model, the authors mention the high perception of corruption and public distrust in the Slovak judiciary (Bobek and Kosar 2013, p. 25). They also mention a perception of politisation of the judiciary (Bobek and Kosar 2013, p. 24) despite the theoretical insulation that the council should have provided, with clear links between politicians and the institution. The Slovak council is an example of how also institutions with limited powers may rise the share of negative assessment by its judges when other aspects of its design and functioning are flawed, thus driving to sub-optimal results.

Table 5 Analysis of sufficient conditions for moderate perception of disrespect to independence

\begin{tabular}{|c|c|c|c|c|c|}
\hline & Incl & PRI & cov.r & cov.u & Cases \\
\hline ASSOCIA_THREAT $\{0\} *$ POWERS $\{0\} *$ & 1.000 & 1.000 & 0.200 & 0.200 & Slovakia \\
\hline \multicolumn{6}{|l|}{ CORRUPT $\{1\} *$ APPOINTMENT $\{1\}$} \\
\hline ASSOCIA_THREAT $\{0\} * \operatorname{POWERS}\{1\} *$ & 1.000 & 1.000 & 0.400 & 0.400 & Romania, Slovenia \\
\hline \multicolumn{6}{|l|}{ CORRUPT $\{0\} *$ APPOINTMENT $\{1\}$} \\
\hline ASSOCIA_THREAT $\{0\} *$ POWERS $\{1\} *$ & 1.000 & 1.000 & 0.200 & 0.200 & Lithuania \\
\hline \multicolumn{6}{|l|}{ CORRUPT $\{1\} *$ APPOINTMENT $\{0\}$} \\
\hline Model & 1.000 & 1.000 & 0.800 & & \\
\hline
\end{tabular}


Compared to Slovakia, Romania - second path - is an interesting instance because it represents the opposite way to reach a moderate perception of disrespect to independence: the country was able to obtain this result even in the presence of a wide range of powers. In this country, the Consiliul Superior al Magistraturii was significantly reformed in 2004 (see Noutcheva and Bechev 2008, p. 134; Iancu 2010 , p. 41). The Romanian council has now nine out of thirteen possible competences in the European Commission Report (2016: 39), including appointment of judges, promotions and disciplinary measures. Although political actors continue to have a role in the appointment of members of the Romanian Council through Senate validation, the reform gave a wider role to judges in the appointment, expanded the number of judicial members of the Council to nine more than half- and curtailed the powers of the Ministry of Justice (Beers 2012: 56). At the same time, the dominant association -'Association or Romanian Magistrates' - has been reluctant to have an active role in political issues and has rather focused on matters such as salaries and workload of judges (Beers 2012: 57). While other, more politically active associations have emerged, these continue to play a minor role (Beers 2012: 58), so the Romanian judicial associative life does not seem to fully mirror yet the partisan logics of the other Latin European countries. Finally. the Consiliul Superior al Magistraturii has been involved in a number of corruption scandals (see Iancu 2010, p. 43; Parau 2012), and Beers (2012: 57) considers that these affected the reputation of the Council 'within the judiciary and among the public'. However, it is interesting to note that despite this the perception of corruption of this institution in the Global Corruption barometer (3.7) was lower than for institutions like Bulgaria (4.4) Lithuania (4.3) or even Portugal (3.9). For just one decimal, Romania was excluded from the set of cases with high judicial corruption, but it is very likely that an improvement in the country's corruption indicator would drive to an even better outcome. In general, the result of Romania is interesting, as it shows that very powerful institutions do not necessarily have to resign themselves with very high perceptions of disrespect to independence.

Indeed, at a cross-case level, this is probably the most remarkable feature of this model: the existence of councils that managed to obtain moderate assessments of disrespect to independence in the presence of a wide range of powers. Cases like Romania, Slovenia and Lithuania, in paths two and three, illustrate this possibility. These cases show that powerful councils can still obtain acceptable results if this is combined with optimal values in the majority of other conditions. Furthermore, these powerful councils managed to obtain these acceptable results even in the presence of hybrid mechanisms of appointment (Romania and Slovenia) or very high perceptions of corruption (Lithuania). Theoretically, with better values in these conditions the outcome could have further improved. The importance of these cases is that they partially break the trade-off between institutional power and perception of respect to independence. They show that under the right conditions powerful councils can still obtain an acceptable assessment by national judges, or at least that they do not have to give up to very negative assessments that pose serious questions over their relation with the judges whose independence they are supposed to protect. 


\section{Conclusion}

The discussion about the most efficient designs of Councils of the Judiciary is an essential aspect of the debate on how to protect the Rule of Law in our societies. However, this discussion is still in the beginning stages of development. Probably due to the scarcity of data, empirical research on the topic is infrequent, which lowers the quality of the academic and social debates regarding these institutions. Although this article has made a step in the direction of overcoming this problem, much more is to be done. This work has made a preliminary exploration of the phenomena based on the only data existing so far, but subsequent studies will have to analyse the Councils in the light of new, more reliable data, addressing also other important aspects of the performance of the institutions. If such endeavor is undertaken, the academia will be making an invaluable contribution to the improvement of our judicial systems.

This article was based on two main presumptions. The first is that the perception of the judges of respect for their independence by their Judicial Council is one important dimension in which to assess the performance of these institutions. The second is that academic research can contribute with evidence-based arguments in an effort to improve the design and functioning of these institutions, in this case by understanding the causes why significant proportion of judges make a negative assessment of their Council. However, it is important to note that judges' perception of respect to their independence is only one of the facets on which Judicial Councils can be assessed. Others, such as their capacity to minimize corruption within the judiciary, public trust in the institution or their ability to manage judicial resources in the most efficient way, to mention just a few, are equally important. Future research will have to attempt at also understanding the dynamics behind those other facets, as well as the interactions between them.

The analyses carried out in this chapter confirmed the presumptions contained in the configurational hypotheses of the research, but added further complexity in understanding the relations between judges and their Councils of the Judiciary. The findings also pointed to some interesting conclusions. To start with, they questioned the matching between powerful Councils of the Judiciary and protection of judicial independence. In fact, significant groups of judges might perceive these powerful institutions as disrespectful of their independence when they are captured by political actors, interest groups and are unable to tackle corruption. Different combinations of these conditions drove to clearly suboptimal judicial assessments of the councils. A good example is the Spanish case: this council, powerful but traditionally controlled by political actors and judicial associations obtained the worst result in the sample. In a moment in which in Spain political debate over the functioning of the Consejo General del Poder Judicial spreads, this article provides an input of empirical information on which aspects of design of the institution should be tackled by any potential reform.

Judicial assessments of powerful councils are slightly better when more of the other conditions work positively; less politicisation of the appointment of members, better assessments of judicial associations, and lower perception of corruption. 
Interestingly enough, it was showed that a disempowered institution was an essential part of the configuration driving to low perception of disrespect to independence, but also that even powerless councils reduce their assessment when other aspects of their design or socio-legal dynamics are sub-optimal. Thus, stripping a Council of its powers does not per se guarantee a smother relation of the institution with the judiciary, and in the absence of other institutional arrangements to protect judicial independence it could drive to unintended negative effects. In this regard, it is important to remember that the threat posed to judicial independence by other actors, and in particular by political actors, might be much more significant. This points to a potential trade-off: disempowered judicial councils might not have many ways to undermine the independence of judges, but neither will they have many tools to protect such independence against the political branches of government.

In any case, the fact is that in many countries Councils of the Judiciary do not seem to have lived to the promise of a more independent judicial system and a stronger Rule of Law, or at least not sufficiently. While centralizing management of the judiciary in these institutions might seem a priori a good idea, flawed institutional designs of Councils can end up being a source of new problems for the courts and judges. In countries where this happens, the correct functioning and integrity of the judiciary, as well as the reputation of the actors that make possible the Rule of Law, can be at stake. In such cases, institutional reform aided by evidence-based analysis should become a priority.

Acknowledgements This paper was finalized during a Visiting Fellowship at the Institute of Advanced Legal Studies, University of London. The paper also benefited from its presentation and discussion at the Faculty of Law of the Universidad de Granada, the Faculty of Law and Political Science of the Universitat de Barcelona and the 2016 Conference of Empirical Legal Studies in Europe. I also want to thank Christoph Hönnige, Steve Farrall, Graham Gee, Javier Lorente, Rosa Navarrete, Iván Medina, David Kosař, Daniel García and Federico Crehuet for their valuable comments on earlier versions of this manuscript. I am especially grateful to the European Network of Councils of the Judiciary for its essential support and feedback during the preparation of the paper. All mistakes and omissions are of the sole responsibility of the author.

Open Access This article is distributed under the terms of the Creative Commons Attribution 4.0 International License (http://creativecommons.org/licenses/by/4.0/), which permits unrestricted use, distribution, and reproduction in any medium, provided you give appropriate credit to the original author(s) and the source, provide a link to the Creative Commons license, and indicate if changes were made.

\section{References}

Andrés Ibáñez P (2003) Veinticinco años de administración de Justicia y Constitución, en Capella, JuanRamón, Las sombras del sistema constitucional español. Trotta, Madrid, pp 151-174

Beers DJ (2012) Judicial self-governance and the rule of law. Evidence from Romania and the Czech Republic. Probl Post Communism 59(5):50-67

Bell J (2006) Judiciaries within Europe: a comparative review. Cambridge University Press, New York, USA 
Berg-Schlosser D, De Meur G, Rihoux B, Ragin C (2009) Qualitative comparative analysis (QCA) as an approach. In: Rihoux B, Ragin C (eds) Configurational comparative methods. SAGE, Thousand Oaks, pp 1-18

Bobek M, Kosar D (2013) Global solutions, local damages: a critical study in judicial councils in Central and Eastern Europe. College of Europe Research Paper in Law 07/2013, at http://aei.pitt.edu/47507/ 1/researchpaper_7_2013_bobek_kosar.pdf. Accessed 7 Nov 2015

Dusa Adrian (2007) User manual for the QCA (GUI) package in R. J Bus Res 60(5):576-586

ENCJ (2010-2011) Councils for the Judiciary report

ENCJ (2014-2015) Independence and accountability of the Judiciary and of the Prosecution

European Commission (2016) The 2016 EU Justice Scoreboard

Ferejohn J (1998-1999) Independent judges, dependent judiciary: explaining judicial independence. South Calif Law Rev 72:353-384

Garoupa Nuno, Ginsburg Tom (2009a) Guarding the guardians: judicial councils and judicial independence. Am J Comp Law 57(1):103-134

Garoupa N, Ginsburg T (2009b) Judicial audiences and reputation: perspectives from comparative law. Columbia J Transnatl Law 47:451-490

Garuopa N, Ginsburg T (2009) The comparative law and economics of judicial councils. Berkeley J Int Law 27(1):53-83

Gee G, Hazell R, Malleson K, O'Brien P (2015) The politics of judicial independence in the UK's changing constitution. OUP, Oxford

Global Corruption Barometer (2010/11-2013) On line at http://www.transparency.org/research/gcb/ overview. Accessed 27 May 2016

Guarneri C (2007) Courts and marginalized groups. Perspectives from Continental Europe. Int J Const Law 5(2):187-210

Guarneri C (2013) Judicial independence in Europe: threat or resource for democracy? Representation 49(3):347-359

Haley JO (2006) Judicial reform: conflicting aims and imperfect models. Wash Univ Glob Stud Law Rev 5:81-97

Hall P, Taylor R (1996) Political science and the three new institutionalisms. Polit Stud 44(5):936-957

Iancu B (2010) Post-accession constitutionalism with a human face: judicial reform and lustration in Romania. Eur Const Law Rev 6(1):28-58

Kato J (1996) Institutions and rationality in politics-three varieties of neo-institutionalists. Br J Polit Sci 26(4):553-582

Magalhaes P (1999) The politics of judicial reform in Eastern Europe. Comp Polit 32(1):43-62

Nieto A (2003) Mecanismos Jurídicos de control del Poder, en Capella, Juan-Ramón, Las sombras del sistema constitucional español. Trotta, Madrid, pp 383-400

Nieto A (2010) El Malestar de los Jueces. Trotta, Madrid

Noutcheva G, Bechev D (2008) The successful laggards: Bulgaria and Romania's accession to the EU. East Eur Polit Soc 22(1):114-144

Parau C (2012) The drive for judicial supremacy in Eastern Europe. In: Seibert-Fohr A (ed.) Judicial independence in transition, Springer, on line at http://oxford.academia.edu/CristinaParau. Accessed 8 Nov 2015

Piana D (2009) The power knocks at the court's back door. Two waves of postcommunist judicial reforms. Comp Polit Stud 42(6):816-840

Popova Maria (2012) Why doesn't the Bulgarian Judiciary Prosecute corruption? Probl Post Communism 59(5):35-49

Rihoux B, Ragin C (eds) (2009a) Configurational comparative methods. SAGE, Thousand Oaks

Rihoux B, Ragin C (2009b) Introduction. In: Rihoux B, Ragin C (eds) Configurational comparative methods. SAGE, Thousand Oaks, pp xvii-xxv

Rosemberg G (1992) Judicial independence and the reality of political power. Rev Polit 54(3):369-398

Schneider C, Wagemann C (2010) Standards of good practice in qualitative comparative analysis (QCA) and fuzzy sets. Comp Sociol 9:1-22

Schneider C, Wagemann C (2012) Set-theoretic methods for the social science. Cambridge University Press, New York, USA

Shepsle KA (2006) Rational choice institutionalism. In: Rhodes RAW, Binder S, Rockman BA (eds) The Oxford handbook of political institutions. OUP, Great Britain, pp 39-55

Van Dijk F, van Tulder F, Lugten Y (2016) Independence of judges: judicial perceptions and formal safeguards, de Rechtspraak Working Paper 2016/1 